\title{
ПРАВОВЫЕ АСПЕКТЫ ПРОЦЕДУРЫ УСТАНОВЛЕНИЯ ТЕРРИТОРИАЛЬНЫХ ЗОН В РОССИЙСКОЙ ФЕДЕРАЦИИ
}

\section{Елена Сергеевна Стегниенко}

Сибирский государственный университет геосистем и технологий, 630108, Россия, г. Новосибирск, ул. Плахотного, 10, старший преподаватель кафедры кадастра и территориального планирования, тел. (383)361-05-66, e-mail: es.st@inbox.ru

\section{Полина Евгенвевна Иваненко}

Сибирский государственный университет геосистем и технологий, 630108, Россия, г. Новосибирск, ул. Плахотного, 10, обучающийся, тел. (923)231-46-54, e-mail: polli-holli@mail.ru

В статье описано значение зонирования для рационального управления развитием территорий. Проанализирована нормативно-правовая база зонирования территорий, рассмотрены последние изменения в градостроительном законодательстве. Выявлены особенности перехода от «землеустроительной» системы зонирования территорий к описанию местоположения границ территориальных зон.

Ключевые слова: градостроительное зонирование территорий, принципы земельного законодательства, градостроительное законодательство, описание местоположения границ, единый государственный реестр недвижимости, территориальное планирование, земли населенных пунктов

\section{LEGAL ASPECTS OF THE PROCEDURE FOR ESTABLISHING TERRITORIAL ZONES IN THE RUSSIAN FEDERATION}

\section{Elena S. Stegnienko}

Siberian State University of Geosystems and Technologies, 10, Plakhotnogo St., Novosibirsk, 630108, Russia, Senior Lecturer, Department of Cadastre and Territorial Planning, phone: (383)361-05-66, e-mail: es.st@inbox.ru

\section{Polina E. Ivanenko}

Siberian State University of Geosystems and Technologies, 10, Plakhotnogo St., Novosibirsk, 630108, Russia, Student, phone: (923)231-46-54, e-mail: polli-holli@mail.ru

The article describes the importance of zoning for the rational management of territories. The regulatory and legal framework of territorial zoning is analyzed, the latest changes in urban planning legislation are considered. The features of the transition from the land management system of territorial zoning to the description of the location of the boundaries of territorial zones are revealed.

Keywords: urban planning zoning of territories, principles of land legislation, town planning legislation, description of the location of borders, unified state register of real estate, territorial planning, land of settlements 
Территориальное планирование представляет собой прогнозирование развития территории на определенный период времени [1]. Такое прогнозирование не представляется возможным без наличия актуальной, достаточной и достоверной информации о территории - в том числе сведений о границах территориальных зон в Едином государственном реестре недвижимости [2].

Одна из основных целей территориального планирования - установление назначения территорий исходя из их социальных, экологических, экономических и иных факторов с учетом интересов граждан. Для земель населенных пунктов первостепенное значение имеет единство правового регулирования использования земельных участков и объектов недвижимости, которые на них расположены.

При планировке и застройке территории ключевым критерием является необходимость ее зонирования с установлением видов функционального использования и ограничений для осуществления градостроительной деятельности. Также необходимо планировать и застраивать территорию с учетом ее природных особенностей. А именно: наименее «удобные» территории должны быть подвергнуты освоению путем проведения инженерно-технических мероприятий, которые связаны с изменением самих природных условий.

Актуальность темы исследования определяется основными началами, идеями российского законодательства и правовой науки. Статья 9 Конституции РФ определяет землю как основу жизни и деятельности человека, а статья 36 запрещает использование земли, если такое использование наносит ущерб окружающей среде [3].

Одним из принципов земельного законодательства является деление земель по целевому назначению на категории, согласно которому правовой режим земель определяется, исходя из принадлежности к той или иной категории и разрешенного использования в соответствии с зонированием территорий и требованиями законодательства. Данный принцип закреплен пунктом 8 части 1 статьи 1 Земельного кодекса РФ и указывает на еще один важный принцип регулирования земельных отношений - все положения о владении, пользовании и распоряжении землями, а также все положения, связанные с охраной и управлением земельным фондом в Российской Федерации, устанавливаются и применяются к конкретным земельным участкам в зависимости от определенной категории земель [4].

Территориальные зоны - это зоны, для которых в правилах землепользования и застройки определены границы и установлены градостроительные регламенты. Порядок установления территориальных зон регулируется статьей 34 Градостроительного Кодекса РФ [1]. Виды территориальных зон и их состав установлены статьей 35 данного нормативно-правового акта (рис. 1).

Зонирование территорий в России регулируется различными нормативноправовыми актами. Основу их правового регулирования составляют Земельный и Градостроительный Кодексы РФ (рис. 2). 


\begin{tabular}{|l|}
\hline жилая зона \\
общественно-деловая зона \\
\hline производственная зона \\
\hline зона инженерной и транспортной инфраструктур \\
\hline зона сельскохозяйственного использования \\
\hline зона особо охраняемых территорий \\
\hline зона рекреационного назначения \\
\hline зона специального назначения \\
\hline зона размещения военных объектов \\
\hline иные виды территориальных зон \\
\hline
\end{tabular}

Рис. 1. Виды территориальных зон по Градостроительному кодексу РФ

Обязанность, сроки и порядок направления документов, содержащихся в них сведений о границах территориальных зон, границах населенных пунктов, необходимых для внесения в ЕГРН, установлены статьей 32 Федерального закона «О государственной регистрации недвижимости» [5]. Уполномоченными на направление являются органы местного самоуправления, соответственно, утвердившие генеральный план либо правила землепользования и застройки.

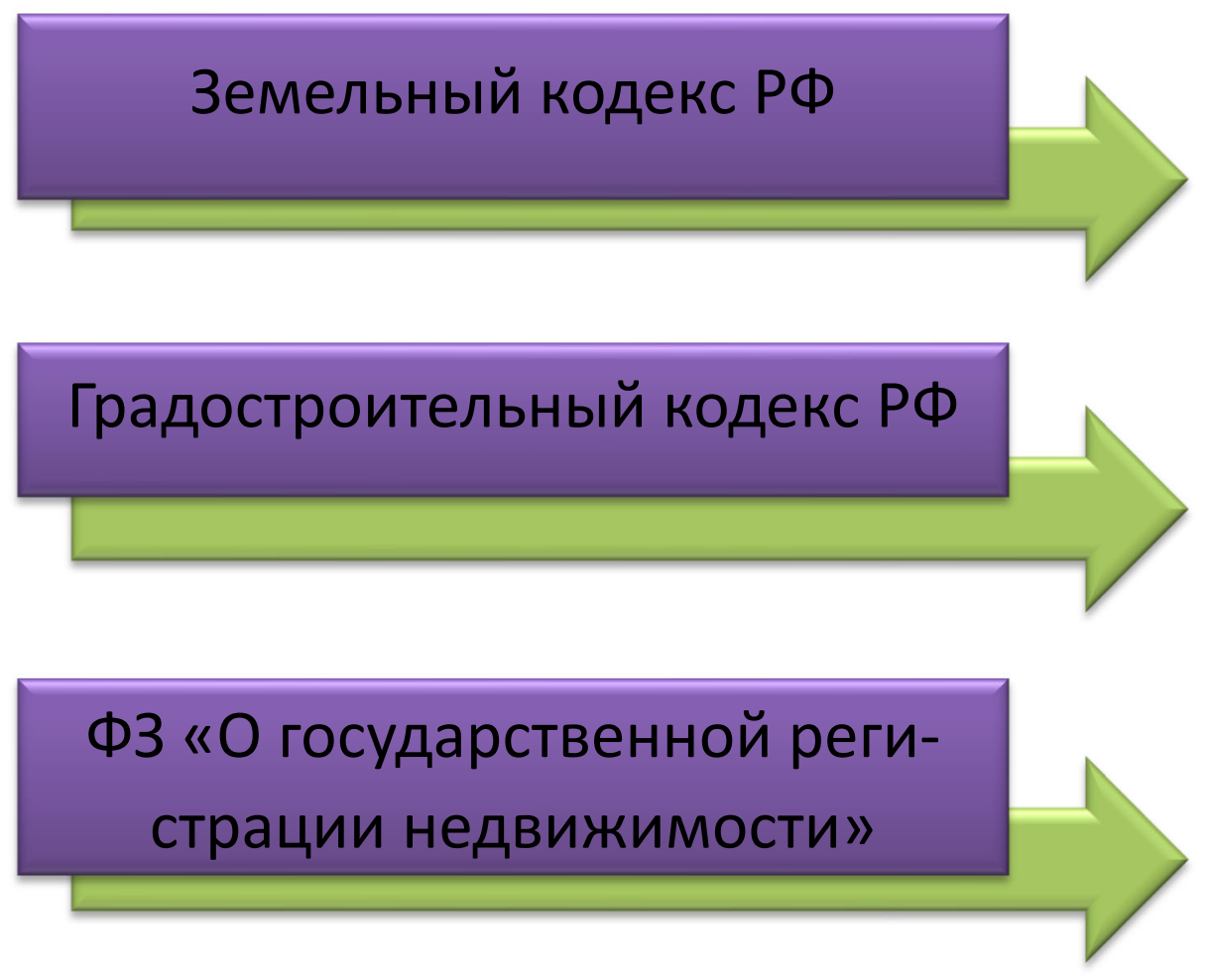

Рис. 2. Нормативно-правовая база градостроительного зонирования территорий в России 
Действующий на данный момент порядок является результатом реформирования части законодательства, он пришел на смену землеустроительному порядку установления территориальных зон.

Согласно редакции Федерального закона «О землеустройстве» до 11 января 2018 года территориальные зоны являлись объектом землеустройства, а итоговым документов выступала карта (план) объекта землеустройства [6].

Федеральным законом «О внесении изменений в Градостроительный кодекс Российской Федерации и отдельные законодательные акты Российской Федерации» территориальные зоны исключены из состава объектов землеустройства [7]. Документ, кроме отдельных положений, вступил в силу 11.01.2018.

Теперь для передачи в ЕГРН сведений о границах населенных пунктов и территориальных зон не требуется подготовка землеустроительных дел, а также карт (планов) объектов землеустройства. Упразднение этой процедуры позволило в несколько раз сократить сроки внесения сведений о местоположении границ населенных пунктов и территориальных зон в ЕГРН.

Их заменили новые документы, содержащие графическое описание местоположения границ указанных территорий и зон, а также перечень координат характерных точек этих границ в системе координат, используемой для ведения ЕГРН. Такие сведения являются обязательным приложением к схеме территориального планирования муниципального района, генеральному плану, правилам землепользования и застройки. Требования к ним (в том числе к форме графического и текстового описания, к точности определения координат характерных точек границ, формату электронного документа) установлены Росреестром [8].

С 2018 года вступил в силу Приказ Министерства экономического развития России [9], установивший форму графического и текстового описания местоположения границ населенных пунктов, территориальных зон, требования к точности определения координат характерных точек границ, формату электронного документа (XML-схемы).

Кроме того, в соответствии с упомянутым выше Федеральным законом [7] с 1 января 2021 года не допускается выдача разрешений на строительство при отсутствии в ЕГРН сведений о границах территориальных зон для земельных участков, на которых планируются строительство, реконструкция объектов капитального строительства [1]. Тем самым так же подтверждается соблюдение принципов земельного законодательства, описанных ранее.

Таким образом, направление реформирования в сфере установления территориальных зон авторам представляется верным. Однако подобные изменения повлекут и сложности в организационной и практической реализации на переходном этапе. Так, например, большое количество ранее учтенных участков в ЕГРН не имеют сведений о координатах характерных точек границ.

В связи с чем, при установлении границ на данной территории необходимо максимально точно определять контур границы территориальной зоны. В противном случае, при уточнении границ ранее учтенных земельных участков могут возникнуть основания для приостановления кадастрового учета в связи с пересечением границ уточняемых участков с границами внесенных зон. 
Законодательно предусмотреть всевозможные проблемы практической реализации - сложная задача, однако, установленные требования к форме документов, процедуре осуществления, функциям и задачам уполномоченных органов позволяют разрешить большую часть споров, возникающих при такой реализации.

\section{БИБЛИОГРАФИЧЕСКИЙ СПИСОК}

1. Градостроительный кодекс Российской Федерации [Электронный ресурс]: федер. закон от 29.12.2004 №190-Ф3. - Доступ из справ.-правовой системы «КонсультантПлюс».

2. Горянова Ольга Федоровна Современные проблемы определения границ территориальных зон // Интерэкспо Гео-Сибирь. 2016. №2. [Электронный pecypc] URL: https://cyberleninka.ru/article/n/sovremennye-problemy-opredeleniya-granits-territorialnyh-zon.

3. Конституция Российской Федерации [Электронный ресурс]: принята всенародным голосованием 12.12.1993 с изменениями, одобренными в ходе общероссийского голосования 01.07.2020. - Доступ из справ.-правовой системы «КонсультантПлюс».

4. Земельный кодекс Российской Федерации [Электронный ресурс]: федер. закон от 25.10.2001 №136-Ф3. - Доступ из справ.-правовой системы «КонсультантПлюс».

5. О государственной регистрации недвижимости [Электронный ресурс]: федер. закон от 13.07.2015 № 218-Ф3. - Доступ из справ.-правовой системы «КонсультантПлюс».

6. О землеустройстве [Электронный ресурс]: федер. закон от 18.06.2001 №78-Ф3 (в редакции 13.07.2015). - Доступ из справ.-правовой системы «КонсультантПлюс».

7. О внесении изменений в Градостроительный кодекс Российской Федерации и отдельные законодательные акты Российской Федерации [Электронный ресурс]: федер. закон от 31.12.2017 N 507-Ф3. - Доступ из справ.-правовой системы «КонсультантПлюс».

8. Оформление документов в отношении территориальных зон: проблемы и решения [Электронный pecypc]. - Режим доступа: https://zen.yandex.ru/media/rkc/oformleniedokumentov-v-otnoshenii-territorialnyh-zon-problemy-i-resheniia-5d91d07ce6cb9b00ad469d30 Загл. с экрана.

9. Об установлении формы графического описания местоположения границ населенных пунктов, территориальных зон, особо охраняемых природных территорий, зон с особыми условиями использования территории, формы текстового описания местоположения границ населенных пунктов, территориальных зон, требований к точности определения координат характерных точек границ населенных пунктов, территориальных зон, особо охраняемых природных территорий, зон с особыми условиями использования территории, формату электронного документа, содержащего сведения о границах населенных пунктов, территориальных зон, особо охраняемых природных территорий, зон с особыми условиями использования территории, и о признании утратившими силу приказов Минэкономразвития России от 23 марта 2016 г. N 163 и от 4 мая 2018 г. N 236 [Электронный ресурс]: Приказ Минэкономразвития России от 23.11.2018 N 650 .

10. О кадастровой деятельности [Электронный ресурс]: федер. закон от 24.07.2007 №221-ФЗ. - Доступ из справ.-правовой системы «КонсультантПлюс».

11. Майоров Евгений Германович, Плахова Елизавета Сергеевна, Митрофанова Наталья Олеговна Порядок установления и внесения в ЕГРН границ территориальных зон на примере Р. П. Краснозерское Новосибирской области // Интерэкспо Гео-Сибирь. 2019. [Электронный pecypc] URL: https://cyberleninka.ru/article/n/poryadok-ustanovleniya-i-vneseniya-v-egrn-granitsterritorialnyh-zon-na-primere-r-p-krasnozerskoe-novosibirskoy-oblasti

12. Беликеев Федор Николаевич О новых принципах установления территориальных зон // Имущественные отношения в РФ. 2013. №1 (137). [Электронный pecypc] URL: https://cyberleninka.ru/article/n/o-novyh-printsipah-ustanovleniya-territorialnyh-zon.

(C) Е. С. Стегниенко, П. Е. Иваненко, 2021 